\title{
Assessment Of Arsenic Exposure In The Population Of Sabalpur Village Of Saran District Of Bihar With Mitigation Approach
}

Arun Kumar ( $\square$ arunk31@rediffmail.com )

Mahavir Cancer Sansthan and Research Centre https://orcid.org/0000-0002-8946-5909

Rishav Kumar

Mahavir Cancer Sansthan and Research Centre

Md. Samiur Rahman

Anugrah Narayan College

Mohammad Ali

Mahavir Cancer Sansthan and Research Centre

\section{Ranjit Kumar}

Central University of Himachal Pradesh

Neha Nupur

Anugrah Narayan College

Aman Gaurav

Anugrah Narayan College

Vikram Raj

Anugrah Narayan College

Gautam Anand

Mahavir Cancer Sansthan and Research Centre

Pintoo Kumar Niraj

Mahavir Cancer Sansthan and Research Centre

Nirmal Kumar

Amity University Rajasthan: Amity University - Jaipur Campus

Abhinav Srivastava

Mahavir Cancer Sansthan and Research Centre

Akhouri Biswapriya

GSI: Geological Survey of India

Gyanendra Bahadur Chand

Patna University

Dhruv Kumar

Amity University

Tuhin Rashmi 
Amity University

\section{Santosh Kumar}

TU Delft: Technische Universiteit Delft

\section{Maiko Sakamoto}

University of Tokyo - Kashiwa Campus: Tokyo Daigaku - Kashiwa Campus

\section{Ashok Kumar Ghosh}

Mahavir Cancer Sansthan and Research Centre

\section{Research Article}

Keywords: Arsenicosis, Health assessment, Cancer, Groundwater contamination, Sabalpur (Bihar)

Posted Date: February 8th, 2021

DOI: https://doi.org/10.21203/rs.3.rs-159875/v1

License: (c) (1) This work is licensed under a Creative Commons Attribution 4.0 International License. Read Full License

Version of Record: A version of this preprint was published at Environmental Science and Pollution Research on April 11th, 2021. See the published version at https://doi.org/10.1007/s11356-021-13521-5. 


\section{Abstract}

Arsenic poisoning through groundwater is the world's greatest normal groundwater catastrophe which got an immense effect on worldwide general wellbeing. India is confronting the outcomes of arsenic poisoning in the zone of Ganga Brahmaputra alluvial plains. In Bihar out of 38 districts, 18 districts are exceptionally influenced with groundwater arsenic defilement. In the present study, we have assessed the current situation of arsenic exposure in Sabalpur village of Saran district of Bihar after reporting of breast, renal, skin and thyroid cancer cases from this village along with typical symptoms of arsenicosis. Such cancer patients were identified at our institute and were taken for the study. The present investigation deals with the quantification of arsenic in groundwater, hair and nail samples as well as the survey of entire village to know the overall health status of the village people. Altogether, 128 groundwater samples through handpumps, 128 human hair and nail samples respectively were collected from over 520 households. Using the Graphite Furnace Atomic Absorption Spectrophotometer (GF-AAS), all the samples were analysed. The investigation resulted that the $61 \%$ of the analysed samples particularly the groundwater had the arsenic levels more than the permissible limit of WHO $(>10 \mu \mathrm{g} / \mathrm{L})$ with $244.20 \mu \mathrm{g} / \mathrm{L}$ as the greatest arsenic contamination in one of the groundwater sample. The exposure effect of hair sample was worst as $88 \%$ of all the collected samples were having high arsenic levels more than the permissible limit $(>0.2 \mathrm{mg} / \mathrm{Kg})$. In case of nails samples, $92 \%$ of the samples were having high arsenic concentration more than the permissible limit $(>0.5 \mathrm{mg} / \mathrm{Kg})$. The health survey study uncovered the exceptionally chronic weakness status of the village populace as individuals were experiencing the issues like asthma, anaemia, hepatomegaly, diabetes, cardiac problem, skin fungal infections, breathlessness, mental disability, etc. Few cancer cases of renal, skin, breast and cervix were also found among the population of this village. The percentage of cancer cases in this village was $0.94 \%$ that is low but it would be an aggravated situation in the near future if people will continue drinking arsenic contaminated water. Therefore, a mitigation intervention was done in March 2020 by installing an arsenic filter plant. The health situation in the present scenario is hope to restore in the village in the coming years. However, motivation and awareness among the village population is still required.

\section{Introduction}

Groundwater arsenic pollution is arising as a significant ecological and human wellbeing catastrophe in the recent times (Bhattacharya et al., 2007; Chakraborti et al., 2004; Kapaj et al., 2006). It is assumed that more than 200 million population are exposed to high arsenic level $(<10 \mu \mathrm{g} / \mathrm{L})$ through drinking water (Argos et al., 2012) and around 13 regions of world are enormously affected by high arsenic level in groundwater aquifers (Kinniburgh et al., 2002). Drinking water is viewed as one of the root cause of inorganic arsenic contamination (Mudhoo et al., 2011; National Research Council, 2001). In Asia, India and Bangladesh are the major affected nations from groundwater arsenic poisoning. Arsenic poisoning is representing an incredible health hazards among individuals living in the Ganga-Brahmaputra-Meghna (GBM) fluvial plains (Singh et al., 2014). In India, Assam, West Bengal, Uttar Pradesh and Bihar are the states which are highly affected by the groundwater arsenic contamination. The Himalayan originated 
river plains are generally severely affected from groundwater arsenic poisoning in the Asian subcontinent. Populace living close to these plain regions are presented to arsenic causing health related issues like keratosis, melanosis, skin disorders, gastro-intestinal disorders and even cancer malignancy (Acharya et al., 1999; Chakraborti et al., 2002; Ahamed et al., 2006; Yunus et al., 2016).

A long-term arsenic exposure result in the accumulation of arsenic in keratinized tissues and also result in other skin manifestations (Shankar et al., 2014). Human hair and nail are the best biomarkers as they reflect the long-term exposure of metals. The arsenic contamiation in hairs and nails reflects the mean arsenic exposure impact in the human body that is during a time of 2-5 months for hair and 12-18 months for nail (Nowak and Kozlowski, 1998; Yoshinaga et al., 1990). They are considered as the significant biomarker, henceforth are generally used to assess the natural arsenic harmfulness (Aghahian et al., 1990; Schegel-Zawadzka, 1992; Nowak et al., 1993; Das et al., 1995; Choudhary et al., 1995; Samanta et al., 2007; Gault et al., 2008; Slotnick et al., 2008).

Bihar is the second most arsenic contaminated state in India. Bihar is divided into 38 districts, out of which 18 districts are exposed to groundwater arsenic pollution. The 15 districts are located in the vicinity of the of the river Ganga basin. It is expected that a populace of around 10 million are drinking arsenic contaminated water with concentration more than 50 $\mathrm{g} / \mathrm{L}$ (Saha, 2009; Singh et al., 2014). In 2002, groundwater arsenic poisoning was first reported in Barisban and Semaria Ojhapatti in the Bhojpur district of Bihar in the middle Ganga plain region (Chakraborti et al., 2003). Arsenic poisoning in these villages prompted numerous wellbeing perils in the populace and numerous individuals exhibited severe symptoms of arsenicosis. Recent investigation on arsenic poisoning in Buxar district, showed serious health hazards in the exposed population, where most extreme groundwater arsenic contamination recorded was $1929 \mu \mathrm{g} / \mathrm{L}$ (Kumar et al., 2016a). In this village, the highest blood arsenic contamination recorded was $664.7 \mu \mathrm{g} / \mathrm{L}$ which is accounted for to be the most elevated till date in the state (Kumar et al., 2016b), lamentably that is the direst outcome imaginable. A critical Indian populace is as yet influenced with arsenicosis symptoms such as diabetes, hypertension, loss of hunger, diarrhoea, stomach torment, breathlessness, hormonal disorders, mental disability and cancer malignancy (Kumar et al., 2015, 2016a, 2019 and 2020; Rahman 2019a and 2019b; Abhinav et al., 2016; Haque, 2003).

Sabalpur village of Sonepur block of Saran district was undertaken for the present study, when patients from this village were accounted for with instances of renal disease and squamous cell carcinoma of skin in our organization. The current study deals with the entire survey of the village along with groundwater, hair and nail arsenic assessment and special emphasis was taken to know about the wellbeing status of the arsenic uncovered populace.

\section{Materials And Methods}

\section{Ethical Approval}

For the present study, ethical approval was obtained from the Institutional Ethics Committee (IEC) of Mahavir Cancer Sansthan \& Research Centre with IEC No. MCS/Research/2015-16/2416, dated 


\section{Location}

The present study was undertaken at Sabalpur village (east) of Sonepur block, Saran district, Bihar, India $\left(25^{\circ} 40^{\prime} 37.4^{\prime \prime} \mathrm{N} 85^{\circ} 10^{\prime} 48.0^{\prime \prime} \mathrm{E}\right)$. The village is situated the confluence of river Ganga and river Gandak

(Fig. 1). The population of the village Sabalpur was approximately 8,006 with male population 4,802 and female population 3,204 (Census, 2011). There were approximately 520 households (Census 2011) in the village.

\section{Sample size}

For the present study, total 128 households (sample size) were randomly selected for samples collection after maintaining a gap of 50 meters that constitutes approximately $25 \%$ of the total households. The $25 \%$ samples were calculated for the study, because each household were closely associated with their boundaries by hardly 5 to 10 metres of the distance from their household handpumps. The study also included the collection of the samples of blood, nail and hair, samples of one individual of the household.

\section{Arsenic analysis}

The water samples were collected in $500 \mathrm{ml}$ polypropylene bottles that were altogether cleaned with distilled water and pre-treated with $2 \%$ hydrochloric acid. Altogether, 128 samples of water were randomly gathered in duplicates from handpumps of every household situated at each 50-70 meters distance in the village. The details of the handpumps such as depths were recorded after the data accumulated from the handpump proprietors and were used for the factual relationship concentrate with arsenic. The hair and nail samples of 128 subjects (selected one member from each studied household) were collected in the zipper polythene packs and prepared for arsenic assessment according to the protocol of (NIOSH, 1994) and processed through Graphite Furnace Atomic Absorption Spectrophotometer (Pinnacle 900T, Perkin Elmer, Singapore) at Mahavir Cancer Sansthan and Research Centre, Patna, Bihar.

\section{Health survey}

The main part of the investigation was the health evaluation study of the populace which was done through the health survey questionnaire proforma. Each person was interviewed in detail through questionnaire in the village. The interview consisted of recording of the data related to the age, sex, number of members in the family, number of children, health related problems, age of the family members suffering from any disease and photo of the diseased person. Apart from this, other questions were also interrogated related to their water sources like handpumps age, depth of the handpump, duration of usage of contaminated water by them, etc. Utilising the handheld Global Positioning System (GPS) receivers (Garmin etrex10, USA), the exact location of the handpump was determined with an estimated accuracy of $\approx 10 \mathrm{~m}$.

\section{Statistical analysis}


Utilising the statistical software GraphPad Prism 5, all the data were analysed with and values expressed as Mean \pm SEM. Through one-way analysis of variance (ANOVA), differences between the groups were statistically analysed by using the Dunnett's test while scattered graphs were plotted through another statistical software IBM SPSS- 25.0 using linear regression analysis.

\section{GIS analysis}

GPS coordinates were overlaid using QGIS software (version 3.10.1-A Coruna), shape file was created and Google map was used as base map. Groundwater arsenic contamination was grouped into 3 classes: $\leq 10,10-50$ and $>50 \mu \mathrm{g} / \mathrm{L}$, whereas, the hair arsenic concentration data was grouped into 2 classes: $\leq 0.2$ and $>0.2 \mathrm{mg} / \mathrm{Kg}$. Similarly, the nail arsenic concentration data was also grouped into 2 classes: $\leq 0.5$ and $>0.5 \mathrm{mg} / \mathrm{Kg}$. Simple A3 landscape layout was chosen for the thematic map output.

\section{Results}

\section{Groundwater arsenic assessment in Sabalpur village}

The collected 128 water sample analysis report showed very high arsenic contamination in the groundwater of the village. The groundwater sample with maximum arsenic concentration reported was $244.20 \mu \mathrm{g} / \mathrm{L}$ while more than $50 \mu \mathrm{g} / \mathrm{L}$ arsenic concentration in about $17 \%$ of the analysed samples were observed, whereas, between $10-50 \mu \mathrm{g} / \mathrm{L}$ arsenic concentration was found in about $44 \%$ of the total

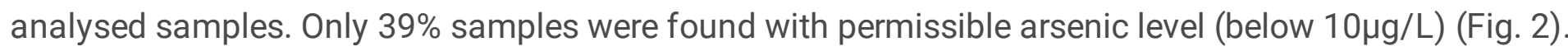

\section{Arsenic analysis in hair samples of village people}

The analysis of 28 hair samples showed arsenic concentration with $12 \%$ below $0.2 \mathrm{mg} / \mathrm{Kg}$ whereas $88 \%$ hair samples were found with the levels more than the permissible limit $(0.2 \mathrm{mg} / \mathrm{Kg})$. The hair arsenic concentration with maximum level of $35.52 \mathrm{mg} / \mathrm{Kg}$ was reported among the studied village population which was extremely high (Fig. 3).

\section{Arsenic analysis in nail samples of village people}

The analysis of 128 nail samples showed arsenic concentration with $8 \%$ below $0.5 \mathrm{mg} / \mathrm{Kg}$ whereas $92 \%$ nail samples were found with the levels more than the permissible limit $(0.5 \mathrm{mg} / \mathrm{Kg})$. The nail arsenic concentration with maximum level of $9.419 \mathrm{mg} / \mathrm{Kg}$ was reported among the studied village population (Fig. 4).

\section{Correlation coefficient Study}

1. Correlation coefficient between the age of the handpump and groundwater arsenic concentration: According to regression analysis, the arsenic levels were prevalently high in the range of 5-22 years old handpumps ( $r=040, P<0.05$; Fig. 5A). 
2. Correlation coefficient between the depth of the handpump and groundwater arsenic concentration: The high arsenic contamination level was prevalent in handpumps between 60-80 feet of depth ranges. An overall declining trend was observed that represent the higher arsenic levels in the shallow aquifers $(r=$ negative, $P<0.05 ; 5 B)$.

3. Correlation coefficient between the age of the subjects and hair arsenic levels. An increasing trend was observed between the subject's age and their hair arsenic level. The subjects over 20 years of age retained higher hair arsenic values representing the age-related hair arsenic deposition $(r=0.022$, $\mathrm{P}<0.05 ; 5 \mathrm{C})$.

4. Correlation coefficient between age of the subjects and the nail arsenic levels. A slight increasing trend was observed between the subject's age and their nail arsenic level. Mostly all the subjects exhibited high nail arsenic level $(r=0.006, P<0.05 ; 5 D)$.

5. Correlation coefficient between the hair arsenic levels and groundwater arsenic concentration: An increasing trend was observed between the subject's hair arsenic level and their drinking water arsenic contamination $(r=0.011, P<0.05 ; 5 E)$.

6. Correlation coefficient between the nail arsenic levels and groundwater arsenic concentration: An increasing trend was observed between the subject's nail arsenic level and their drinking water arsenic contamination $(r=0.011, P<0.05,5 F)$.

\section{GIS study}

The thematic map shows significant synoptic view of groundwater arsenic contamination in Sabalpur village with hair and nail arsenic levels distribution in the village exposed population (Fig. 6).

\section{Clinical Observations}

The village population exhibited typical arsenicosis symptoms such as hyperkeratosis in sole and palm. The average population had more or less the rain drop pigmentation in their body parts. In children the arsenicosis symptoms were seen in only one subject, who also had the lump (cervical node) on her neck (Fig. 7).

\section{Health Assessment}

Few subjects of this village (total subjects, $n=637$ ) exhibited severe symptoms of arsenicosis in the form of hyperkeratosis in palm and sole $(0.01 \%)$, and melanosis $(0.01 \%)$ while other skin problems $(14.29 \%)$, anaemia $(24.01 \%)$, general body weakness $(17.89 \%)$, blood pressure problem $(15.07 \%)$, diabetes (8.477\%), breathlessness (13.81\%), mental disability (2.99\%), lump in the body $(17.74 \%)$ and other health problem $(28.88 \%)$ were also observed (Table 1$)$.

\section{Cancer cases}

In the present study, the most unfortunate part was when a cancer patient reported to our institute with typical symptoms of arsenicosis all over the body. The patient was diagnosed with renal cell carcinoma. 
The patient's drinking water source was assayed which was found to be $172.6 \mu \mathrm{g} / \mathrm{L}$, while the arsenic concentration in blood was $245.6 \mu \mathrm{g} / \mathrm{L}$, nail was $353.1 \mu \mathrm{g} / \mathrm{Kg}$ and in hair was $182.4 \mu \mathrm{g} / \mathrm{Kg}$ respectively (Fig. 8).

\section{Mitigation Intervention}

In the present study area, the mitigation approach was undertaken to combat the problem in March 2020 by the installation of an arsenic filter (ceramic membrane based arsenic filter) by the joint association of CSIR-CGCRI, Kolkata, Bihar State Pollution Control Board, Patna and WaterAid- Bihar. This will be solving the exposed population at much extent. The health review shall be conducted after the operation of 18 months of this installed arsenic filter to know the impact at the initial phase (Fig. 9).

\section{Discussion}

The US Environmental Protection Agency (EPA) and World Health Organization (WHO) suggested a maximum level of $10 \mu \mathrm{g} / \mathrm{L}$ inorganic arsenic level in groundwater is viewed as safe for drinking purpose (ATSDR, 2005; Rakib et al., 2013; WHO, 1993). Arsenic was positioned as number one general human health impact on its substance priority list by United States Agency for Toxic Substances and Disease Registry considering it as a carcinogen causing cancer of lung, kidney, bladder and skin (ATSDR, 2005). International Agency for Research on Cancer grouped inorganic arsenic as class I human cancer-causing agent, which means adequate evidence supported their classification (IARC, 2012; Martinez et al., 2011; WHO, 2011). The Joint Food and Agriculture Organization of the United Nations/World Health Organization (WHO) Expert Committee on Food Additives (JECFA) re-examined the risks of arsenic exposure and found evidence of adverse impacts in regions with drinking water arsenic concentration ranging between 50 to $100 \mu \mathrm{g} / \mathrm{L}(\mathrm{WHO}, 2011)$.

An estimated 200 million individuals are exposed to arsenic level unquestionably more than the permissible limit, caused different arsenic related diseases (Naujokas et al., 2013; IARC, 2004; Gregori et al., 2003; Nordstorm, 2002; Smith et al., 2000). A new report in 2012 assessed that around 20-45 million individuals are at high risk of arsenic exposure more than $50 \mu \mathrm{g} / \mathrm{L}$ concentration (Flanagan et al., 2012). According to a recent study, cancer risk is related with normal day by day utilization of 2 litres of drinking water with more than $50 \mu \mathrm{g} / \mathrm{L}$ inorganic arsenic. The main source of inorganic arsenic exposure is mostly through drinking water and water-based products (Sinha et al., 2003; Anetor et al., 2007; Chung et al., 2014). The present study revealed the highest groundwater arsenic concentration found to be $244.20 \mu \mathrm{g} / \mathrm{L}$ in studied area which is around 24 times greater than the WHO maximum permissible limit. Around $61 \%$ of the handpumps were found to be contaminated with more than $10 \mu \mathrm{g} / \mathrm{L}$ arsenic concentration that is problematic situation for the residing population. The highly elevated arsenic levels were found between 60-80 feet of handpump depth range.

The arsenic toxicity symptoms primarily manifest on skin along with disturbances in other cellular process of organ systems. The arsenic caused skin manifestation appears with hyperpigmentation, hyperkeratosis, hypermelanosis of the palm and sole (Li et al, 2011; Melkonian et al., 2012). In the present 
study also, many arsenic exposed subjects exhibited the symptoms of arsenicosis like hyperkeratosis, hyperpigmentation and melanosis in their palm and sole.

Hair and nail reflect the long-term exposure of metals. The arsenic concentration in hair and nails reflect its average level in the human body for a period of 2-5 months in hairs and 12-18 months in nails (Yoshinaga et al., 1990, Nowak and Kozlowski, 1998). USEPA, WHO and Atomic Energy Agency (AEA) recommended the use of hair as an important biomarker for worldwide environmental arsenic monitoring (Druyan et al., 1998; Morton et al., 2002). Generally arsenic persists for longer time duration in hairs (Gebel et al., 2000). Blood arsenic moves into hairs and retain there by binding with the sulfhydryl groups of keratin and finally moves toward the hair shafts (Hindmarsh, 2002). Our present study explored the highest arsenic level in human hair samples that was $35.52 \mathrm{mg} / \mathrm{Kg}$ among the studied population. Even the younger age group from village were also having high arsenic concentrations in their hair. Arsenic also persists for longer time duration in nails just like hairs. The present study showed that the nail samples retain lower values of arsenic concentration with the maximum of $9.419 \mathrm{mg} / \mathrm{Kg}$ in comparison with hair samples.

The studied population's health status was very poor as they were suffering from health issues like asthma, anaemia, hepatomegaly, diabetes, cardiac problems, fungal infection on skin, breathlessness and mental disability. Regular consumption of drinking water contaminated with elevated arsenic levels resulted in the high risk of skin, bladder, lung, liver and kidney cancer (Chowdhury et al., 2000; GuhaMazumder et al., 1998; Berg et al., 2001; Chen et al., 1999; Ferreccio et al., 2000). Long term arsenic exposure led towards early onset of diabetes (Benbrahim-Tallaa and Waalkes et al., 2008). In our present study some diabetic cases were found and the most unfortunate part of the study was the finding of few cancer cases of renal, skin, breast and cervix. Hence, arsenic in the present scenario is enhancing the disease burden in the arsenic exposed population. However, after the installation of the arsenic filter in this village will definitely change the scenario in this village and will also change the health status of the exposed population. Hence, from the present study, it can be concluded that, arsenic contamination in drinking water is causing lot of health-related problems in the exposed population of village Sabalpur. The disease burden in the studied village population is very high. However, after the installation of the arsenic filter in the village will definitely play the major role to control the disease burden in the coming years.

\section{Declarations}

Acknowledgement: The authors acknowledge support extended by Mahavir Cancer Institute and Research Centre, Patna for providing laboratory and other infrastructural facilities for this study. We are also thankful to Dr. Swaccha Majumdar, CSIR-CGCRI, Kolkata, Bihar State Pollution Control Board, Patna and WaterAid- Bihar for the installation of the arsenic filter in this village.

Funding: This work was financially supported by the institute itself (Mahavir Cancer Sansthan and Research Centre, Patna, Bihar, India) 
Data availability: All data generated or analyzed during this study are included in this manuscript.

\section{Compliance with ethical standards}

Conflict of interest: The authors declare that they have no conflicts of interest.

Ethical approval: For the present study, ethical approval was obtained from the Institutional Ethics Committee (IEC) of Mahavir Cancer Sansthan \& Research Centre with IEC No. MCS/Research/201516/2416, dated 24/08/2016 (agenda no.15).

Consent to participate: Not applicable

Consent to publish: All authors have read the manuscript and approve of its submission to Environmental Science and Pollution Research.

Author Contributions: A.K., M.A, R.K and A.K.G. Conceptualized the entire work, A.K. had the major contributions in writing the manuscript but support was also provided by A.K.G., D.K., T.R. and A.B., literature search was done by A.S. and P.K.N., survey data were collected by M.S.R., R.K., N.K., N.N., A.G., V.R., G.A., and P.K.N, experimental work and data analysis were done by M.S.R., P.K.N, G.A. and A.S. data interpretation was carried out by A.K., M.A., R.K., D.K., A.B., T.R, G.B.C and M.S., geospatial mapping was finalised by A.B., S.K., and M.S.R., and final figures were designed by A.K. M.S.R, R.K. and S.K. All authors read and approved the final paper.

\section{References}

1. Abhinav S, Navin S, Verma SK, Kumar R, Ali M, Kumar A, Ghosh AK. (2016). Groundwater and blood samples assessment for arsenic toxicity in rural population of Darbhanga district of Bihar, India. In: Proceedings of the 6th International congress on arsenic in the environment, Stockholm, Sweden, 19-23 June 2016. Arsenic Research and Global Sustainability As 2016, Taylor \& Francis group, London. 418-420.

2. Acharya SK, Chakraborty P, Lahiri S, Raymahashay BC, Guha S, Bhowmik A. (1999). Arsenic poisoning in the Ganges delta. Nature. 401:545.

3. Agahian B, Lee JS, Nelson HJ, Johns RE. (1990). Arsenic levels in fingernails as a biological indicator of exposure to arsenic. Am Ind Hyg Assoc J. 51:646-651.

4. Ahamed S, Sengupta MK, Mukherjee A, Hossain MA, Das B, Nayak B, Pal A, Mukherjee SC, Pati S, Dutta RN, Chatterjee G, Mukherjee A, Srivastava R, Chakraborti D. (2006). Arsenic groundwater contamination and its health effects in the state of Uttar Pradesh (UP) in upper and middle Ganga plain, India: a severe danger. Sci Total Environ. 370(2-3):310-322.

5. Anetor, J. I., Wanibuchi, H., \& Fukushima, S. (2007). Arsenic exposure and its health effects and risk of cancer in developing countries: micronutrients as host defence. Asian Pacific journal of cancer prevention : APJCP, 8(1), 13-23. 
6. Argos M, Ahsan H, Graziano JH. (2012). Arsenic and human health: epidemiologic progress and public health implications. Rev Environ Health. 27(4):191-195.

7. ATSDR. (2005). US Agency for Toxic Substances and Diseases Registry. Toxicological Profile for Arsenic.

8. Benbrahim-Tallaa L, Waalkes MP. (2008). Inorganic arsenic and human prostate cancer. Environmental Health Perspectives. 116:158-164.

9. Berg M, Tran HC, Nguyen TC, Pham HV, Schertenleib R, Giger W. (2001). Arsenic contamination of groundwater and drinking water in Vietnam: a human health threat. Environ Sci Technol. 35:26212626.

10. Bhattacharya P, Welch AH, Stollenwerk KG, McLaughlin MJ, Bundschuh J, Panaullah G. (2007). Arsenic in the environment: Biology and Chemistry. Science of the Total Environment. 379:109-120.

11. Census. (2011). Interim Report of Population Census of India. (http://www.censusindia.gov.in/).

12. Chakraborti D, Rahman MM, Chowdhury UK, Paul K, Chowdhury UK, Sengupta MK, Lodh D, Chanda CR, Saha KC, Mukherjee SC. (2002). Arsenic calamity in the Indian subcontinent: What lessons have been learned? Talanta. 58:3-22.

13. Chakraborti D, Mukherjee SC, Pati S, Sengupta MK, Rahman MM, Chowdhury UK, Lodh D, Chanda CR, Chakraborti AK, Basu GK. (2003). Arsenic groundwater contamination in Middle Ganga Plain, Bihar, India: a future danger? Environ Health Perspect. 111:1194-1201.

14. Chakraborti D, Sengupta MK, Rahaman MM, Ahamed S, Chowdhury UK, Hossain MA. (2004). Groundwater arsenic contamination and its health effects in the Ganga-Megna-Brahmaputra Plain. Journal of Environmental Monitoring. 6:74-83.

15. Chaudary K, Ehmann WD, Regan K, Markesebery WR. (1995). Trace element correlations with age and sex in human fingernails. J Radioanal Chem. 195:51-65.

16. Chen K-LB, Amarasiriwardena CJ, Christiani DC. (1999). Determination of total arsenic concentrations in nails by inductively coupled plasma mass spectrometry. Biol Trace Elem Res. 67:109-125.

17. Chowdhury UK, Biswas BK, Chowdhury TR, Samanta G, Mandal BK, Basu GC, Chanda CR, Lodh D, Saha KC, Mukherjee SK, Roy S, Kabir S, Quamruzzaman Q, Chakraborti D. (2000). Groundwater arsenic contamination in Bangladesh and West Bengal, India. Environ Health Perspect. 108(5):393397.

18. Chung, J. Y., Yu, S. D., \& Hong, Y. S. (2014). Environmental source of arsenic exposure. Journal of preventive medicine and public health = Yebang Uihakhoe chi, 47(5), 253-257.

19. Das D, Chatterjee A, Mandal BK, Samanta G, Chakraborti D, Chanda B. (1995). Arsenic in ground water in six districts of West Bengal, India: the biggest arsenic calamity in the world, Part 2. Arsenic concentration in drinking water, hair, nails, urine, skin-scale and liver tissue (Biopsy) of the affected people. Analyst. 120:917-924.

20. Druyan ME, Bass D, Puchyr R, Urek K, Quig D, Harmon E, Marquardt W. (1998). Determination of reference ranges for elements in human scalp hair. Biol Trace Elem Res. 62:183-197. 
21. Ferreccio C, Gonzalez C, Milosavjlevic V, Marshall G, Sancha' AM, Smith AH. (2000). Lung cancer and arsenic concentrations in drinking water in Chile. Epidemiology. 11:673-679.

22. Flanagan SV, Johnston RB, Zheng Y. (2012). Arsenic in tube well water in Bangladesh: health and economic impacts and implications for arsenic mitigation. Bull. World Health Organ. 90(11):839-846.

23. Gault AG, Rowland HAL, Charnock JM, Woelius RA, GomezMorilla I, Vong S, Leng M, Sarnreth S, Sampson ML, Polya DA. (2008). Arsenic in Hair and Nails of Individuals Exposed to Arsenic-Rich Groundwaters in Kandal Province, Combodia. Sci. Total Environ. 393:168-176.

24. Gregori ID, Fuentes E, Rojas M, Pinochet H, Potin-Gautier M. (2003). Monitoring of copper, arsenic and antimony levels in agricultural soils impacted and non-impacted by mining activities, from three regions in Chile. Journal of Environmental Monitoring. 5(2):287-295.

25. GuhaMazumder DN, Haque R, Ghosh N, De BK, Santra A, Chakraborty D, Smith AH. (1998). Arsenic levels in drinking water and the prevalence of skin lesions in West Bengal, India. Int J Epidemiol. 27:871-877.

26. Haque R, Mazumdar DNG, Samanta S, Ghosh N, Kalman D, Smith MM, Mitra S, Santra A, Lahiri S, Das S, De BK, Smith AH. (2003). Arsenic in drinking water and skin lesions: Dose-response data from West Bengal, India. Epidemiology. 14(2):174-182.

27. Hindmarsh JT. (2002). Caveats in hair analysis in chronic arsenic poisoning. Clinical Biochemistry. 35:1-11.

28. International Agency for Cancer Research (IARC). (2004). Some drinking-water disinfectants and contaminants including arsenic, in IARC: Monographs on the Evaluation of Carcinogenic Risks to Humans. Vol.84.

29. International Agency for Research on Cancer (IARC). (2012). Lyon, France: World Health Organization. A Review of Human Carcinogens: Arsenic, Metals, Fibres, and Dusts, Vol. 100C, IARC Monographs on the Evaluation of Carcinogenic Risks to Humans.

30. Kapaj S, Peterson H, Liber K, Bhattacharya P. (2006). Human health effects from chronic arsenic poisoning - a review. Journal of Environmental Science Health Part A, Environmental Science Engineering Toxic Hazard Substance Control. 41:2399-2428.

31. Kinniburg DG, Kosmus W. (2002). Arsenic contamination in groundwater: some analytical considerations. Talanta, 58:165-180.

32. Kumar A, Ali Md, Rahman S Md, Iqubal A Md, Anand G, Niraj PK, Shankar P, Kumar R. (2015). Ground Water Arsenic Poisoning in "Tilak Rai Ka Hatta" Village of Buxar District, Bihar, India Causing Severe Health Hazards and Hormonal Imbalance. J Environ Anal Toxicol. 5:290.

33. Kumar A, Kumar R, Rahman MS, Iqubal M, Ali M, Niraj PK, Anand G, Prabhat K, Abhinav, Ghosh AK. $\left(2016^{\mathrm{a}}\right)$. Ground water arsenic contamination: A local survey in India. Int. J. Prev. Med. 7:100.

34. Kumar A, Kumar R, Ali M, Gahlot V, Ghosh AK. $\left(2016^{\text {b }}\right)$. Groundwater Arsenic poisoning in Buxar district of Bihar. Proceedings of the $6^{\text {th }}$ International congress on arsenic in the environment, 
Stockholm, Sweden, 19-23 June 2016, Arsenic Research and Global Sustainability As2016, Taylor \& Francis group, London. 378-379.

35. Kumar A, Rahman MS, Kumar R, Ali M, Niraj PK, Srivastava A, Singh SK, Ghosh AK. (2019). Arsenic contamination in groundwater causing impaired memory and intelligence in school children of Simri village of Buxar district of Bihar. J Mental Health Hum Behav. 24:132-138.

36. Kumar A, Ali M, Kumar R, Rahman MS, Srivastava A, Chayal NK, Sagar V, Kumari R, Parween S, Kumar R, Niraj PK, Anand G, Singh SK, Ghosh AK. (2020). High Arsenic Concentration in Blood Samples of People of Village Gyaspur Mahaji, Patna, Bihar Drinking Arsenic-Contaminated Water. Expo Health. 12:131-140.

37. Li C, Xu J, Li F, Chaudhary SC, Weng Z, Wen J, Weng Z, Wen J, Elmets CA, Ahsan H, Athar M. (2011). Unfolded protein response signaling and MAP kinase pathways underlie pathogenesis of arsenicinduced cutaneous infammation. Cancer Prev Res. 4(12):2101-2109.

38. Martinez VD, Vucic EA, Becker-Santos DD, Gil L, Lam WL. (2011). Arsenic exposure and the induction of human cancers. J Toxicol. 431287.

39. Melkonian S, Argos M, Chen Y, Parvez F, Pierce B, Ahmed A, Islam T, Ahsan H. (2012). Intakes of several nutrients are associated with incidence of arsenic-related keratotic skin lesions in Bangladesh. J. Nutr. 142(12):2128-2134.

40. Morton J, Carolan VA, Gardiner PHE. (2002). Removal of exogenously bound elements from human hair by various washing procedures and determination by inductively coupled plasma mass spectrometry. Anal Chim Acta. 455:23-34.

41. Mudhoo A, Sharma SK, Garg VK, Tseng C-H. (2011). Arsenic: an overview of applications, health, and environmental concerns and removal processes. Critical Reviews in Environmental Science and Technology. 41:435-519.

42. National Research Council. (2001). Arsenic in drinking water-Update. Washington DC, National Academy Press.

43. Naujokas MF, Anderson B, Ahsan H, Aposhian HV, Graziano JH, Thompson C, Suk WA. (2013). The broad scope of health effects from chronic arsenic exposure: update on a worldwide public health problem. Environ. Health Perspect. 121(3):295-302.

44. NIOSH (National Institute for Occupational Safety and Health). (1994). Elements in blood or tissue. Method: 8005. In: NIOSH manual of analytical methods. 4th Edition. O.H. Cincinnati: Department of Health and Human Service, National Institute of Occupational Safety and Health. DHHS publication. 94-113.

45. Nordstrom DK. (2002). Public health. Worldwide occurrences of arsenic in ground water. Science. 296:2143-2145.

46. Nowak B. (1993). Levels of heavy metals in the biological tests (hair, teeth) as an indicator of the environment pollution, in: International Conference-Heavy Metals in the Environment. 2:408-411.

47. Nowak B, Kozlowski H. (1998). Heavy metals in human hair and teeth: The correlation with metal concentration in the environment. Biol Trace Elem Res. 62:213-228. 
48. Rahman MS, Kumar A, Kumar R, Ali M, Ghosh AK, Singh SK. (2019a). Comparative quantification study of arsenic in the groundwater and biological samples of Simri village of Buxar District, Bihar, India. Indian J. Occup. Environ. Med. 23:126-132.

49. Rahman MS, Kumar A, Kumar R, Ali M, Ghosh AK, Singh SK. $\left(2019^{b}\right)$ Hematological and Free Radicals Changes among People of Arsenic Endemic Region of Buxar District of Bihar, India. Int. J. Pub. Health Safe. 4:178.

50. Rakib MA, Huda ME, Hossain SM, Naher K, Khan R, Sultana MS, Akter MS, Bhuiyan MAH, Patwary MA. (2013). Arsenic Content in Inactive Tissue: Human Hair and Nail. Journal of Scientific Research and Reports. 2(2):522-535.

51. Saha D. (2009). Arsenic groundwater contamination in parts of middle Ganga plain, Bihar. Curr Sci. 97(6):753-755.

52. Samanta G, Das D, Mandal BK, Chowdhury TR, Chakraborti D, Pal A, Ahamed S. (2007). J. Environ. Sci. Health Part A-Toxic/Hazard. Subst. Environ. Eng. 42:1815.

53. Schegel-Zawadzka M. 1992. Chromium content in the hair of children and students in Southern Poland. Biol Trace Elem Res. 32:79-84.

54. Shankar S, Shanker U, Shikha. (2014). Arsenic contamination of groundwater: a review of sources, prevalence, health risks and strategies for mitigation. Sci World J. 304524.

55. Singh SK, Ghosh AK, Kumar A, Kislay K, Kumar C, Tiwari RR, Parwez R, Kumar N, Imam MD. (2014). Groundwater Arsenic contamination and associated health risks in Bihar, India. Int. J. Environ Res. 8(1):49-60.

56. Sinha, S. K., Misbahuddin, M., \& Ahmed, A. N. (2003). Factors involved in the development of chronic arsenic poisoning in Bangladesh. Archives of environmental health, 58(11), 699-700.

57. Slotnick MJ, Meliker JR, Nriagu JO. (2008). J. Expo. Sci. Environ. Epidemiol. 18:149.

58. Smith AH, Lingas EO, Rahman M. (2000). Contamination of drinking-water by arsenic in Bangladesh: a public health emergency, Bulletin of the World Health Organization. 78(9):1093-1103.

59. WHO (World Health Organization). (1993). WHO guidelines for drinking-water quality, WHO, Geneva, Switzerland.

60. WHO (World Health Organization). (2011). Background Document for Development of WHO Guidelines for Drinking Water Quality. Geneva, Switzerland: World Health Organization; Arsenic in Drinking Water.

61. Yoshinaga J, Imani H, Nakazawa M, Suzuki T. (1990). Lack of significantly positive concentrations in hair. Sci Total Environ. 99:125-135.

62. Yunus FM, Khan S, Chowdhury P, Milton AH, Hussain S, Rahman M. (2016). A Review of Groundwater Arsenic Contamination in Bangladesh: The Millennium Development Goal Era and Beyond. Naidu R, Rahman MM, eds. International Journal of Environmental Research and Public Health. 13(2):215.

\section{Table}


Table 1. Showing arsenic caused common symptoms and their percentage in the Sabalpur village population

\begin{tabular}{|lllll|}
\hline Symptoms & $\begin{array}{l}\text { Problems present in the } \\
\text { population }\end{array}$ & $\begin{array}{l}\text { No Problems } \\
\text { Observed }\end{array}$ & $\begin{array}{l}\text { Total } \\
\text { Cases }\end{array}$ & $\begin{array}{c}\text { P- } \\
\text { Value }\end{array}$ \\
\hline $\begin{array}{l}\text { Arsenicosis symptoms in } \\
\text { palm and sole }\end{array}$ & $7(0.01 \%)$ & $630(99.99 \%)$ & 637 & $<$ \\
\hline Melanosis in palm and trunk & $7(0.01 \%)$ & $630(99.99 \%)$ & 637 & $<$ \\
\hline Other skin problems & $91(14.29 \%)$ & $546(85.71 \%)$ & 637 & 0.001 \\
\hline Anaemia & $153(24.01 \%)$ & $484(75.99 \%)$ & 637 & 0.001 \\
\hline General Body Weakness & $114(17.89 \%)$ & $523(82.11 \%)$ & 637 & 0.001 \\
\hline BP Problem & $96(15.07 \%)$ & $541(84.93 \%)$ & 637 & 0.001 \\
\hline Diabetes & $54(8.477 \%)$ & $583(91.53 \%)$ & 637 & $<$ \\
\hline Breathlessness & $88(13.81 \%)$ & $553(86.19 \%)$ & 637 & 0.001 \\
\hline Mental Disability & $19(2.99 \%)$ & $618(97.01 \%)$ & 637 & $<$ \\
\hline Lump in the body & $113(17.74 \%)$ & $524(82.26 \%)$ & 637 & $<$ \\
\hline Cancer & $6(0.94 \%)$ & $631(99.05 \%)$ & 637 & $<$ \\
\hline Other Health Problem & $184(28.88 \%)$ & & & 0.001 \\
\hline
\end{tabular}

\section{Figures}




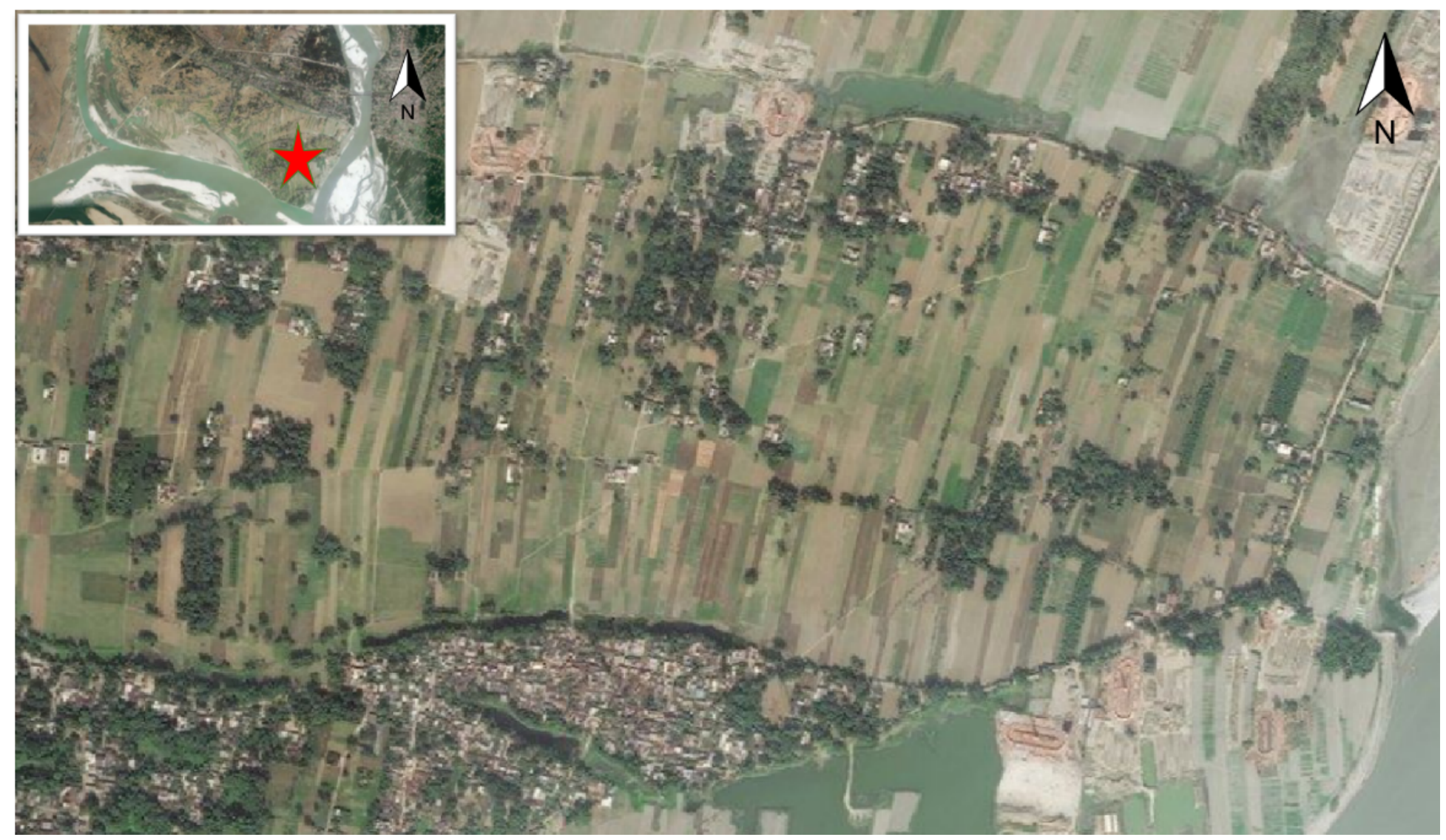

\section{Figure 1}

Aerial view of the arsenic exposed Sabalpur village along with inset river Ganga and river Gandak Note: The designations employed and the presentation of the material on this map do not imply the expression of any opinion whatsoever on the part of Research Square concerning the legal status of any country, territory, city or area or of its authorities, or concerning the delimitation of its frontiers or boundaries. This map has been provided by the authors. 


\section{Groundwater arsenic level in Sabalpur village handpumps $(n=128)$}

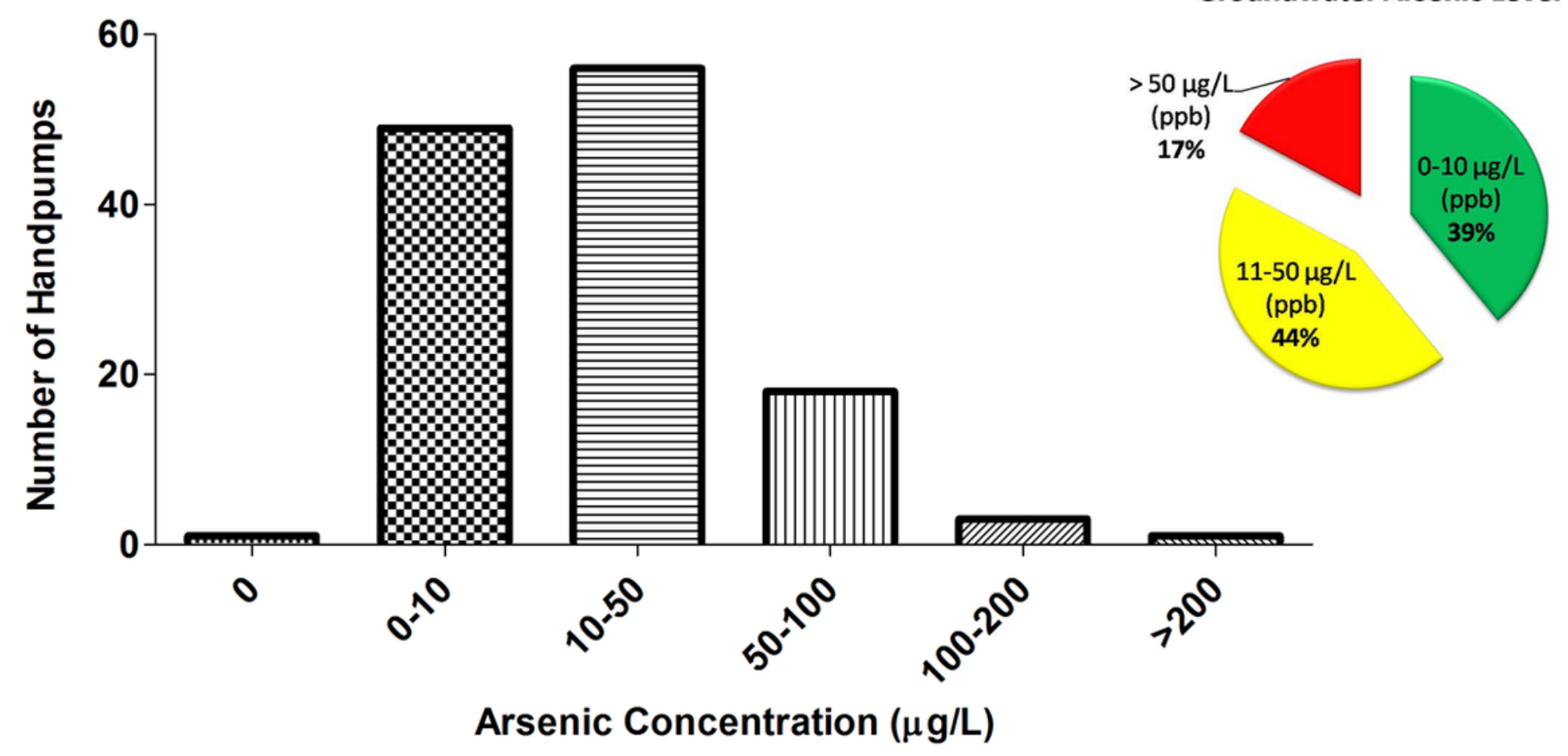

Figure 2

Groundwater arsenic concentration in handpumps of Sabalpur village analysed through GF-AAS (ANOVADunnett's Test, $P<0.05$ ) 


\section{Hair arsenic concentration in Sabalpur village population $(n=128)$}

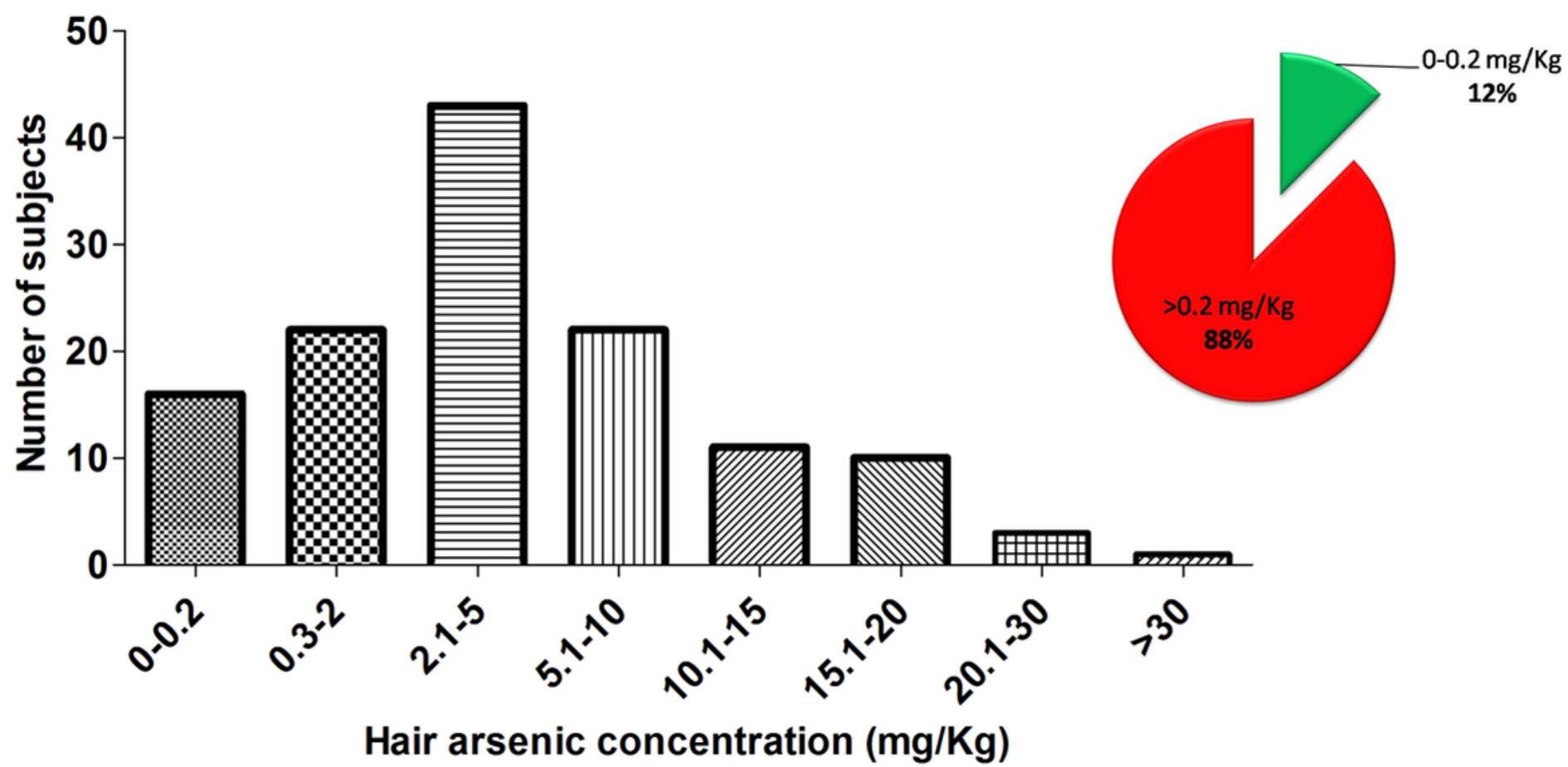

Figure 3

Hair arsenic concentration of Sabalpur village population analysed through GF-AAS (ANOVA- Dunnett's Test, $\mathrm{P}<0.05)$ 
Nail arsenic concentration in Sabalpur

village population $(n=128)$

Nail Arsenic Level

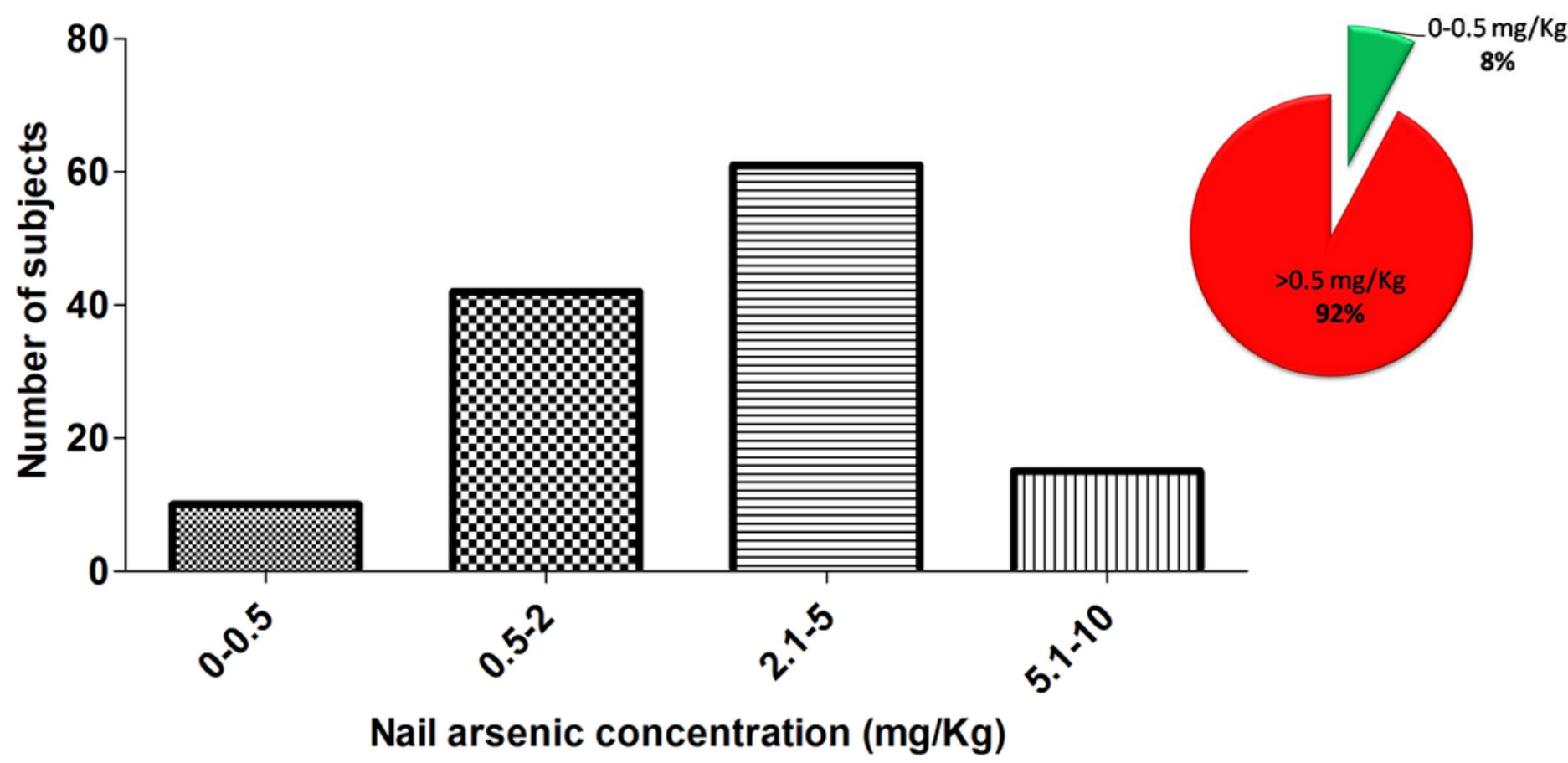

Figure 4

Nail arsenic concentration of Sabalpur village population analysed through GF-AAS (ANOVA- Dunnett's Test, $\mathrm{P}<0.05)$ 


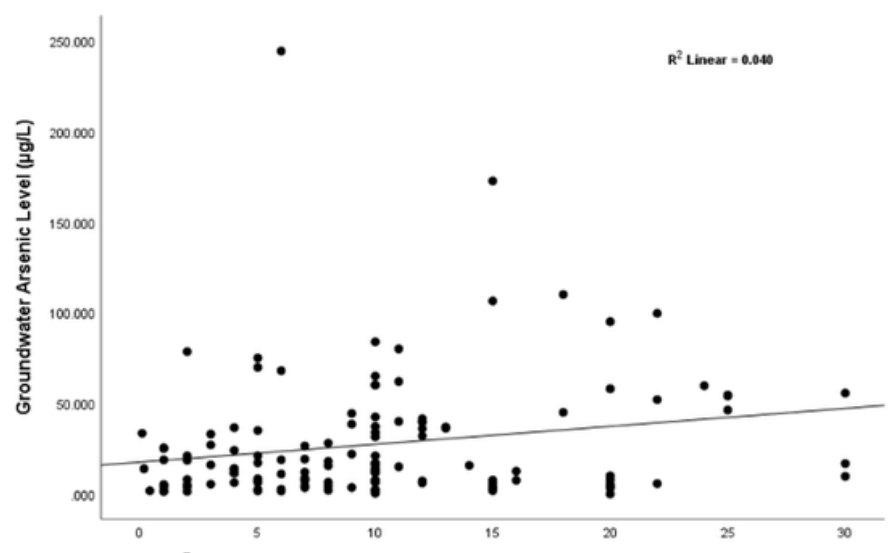

A
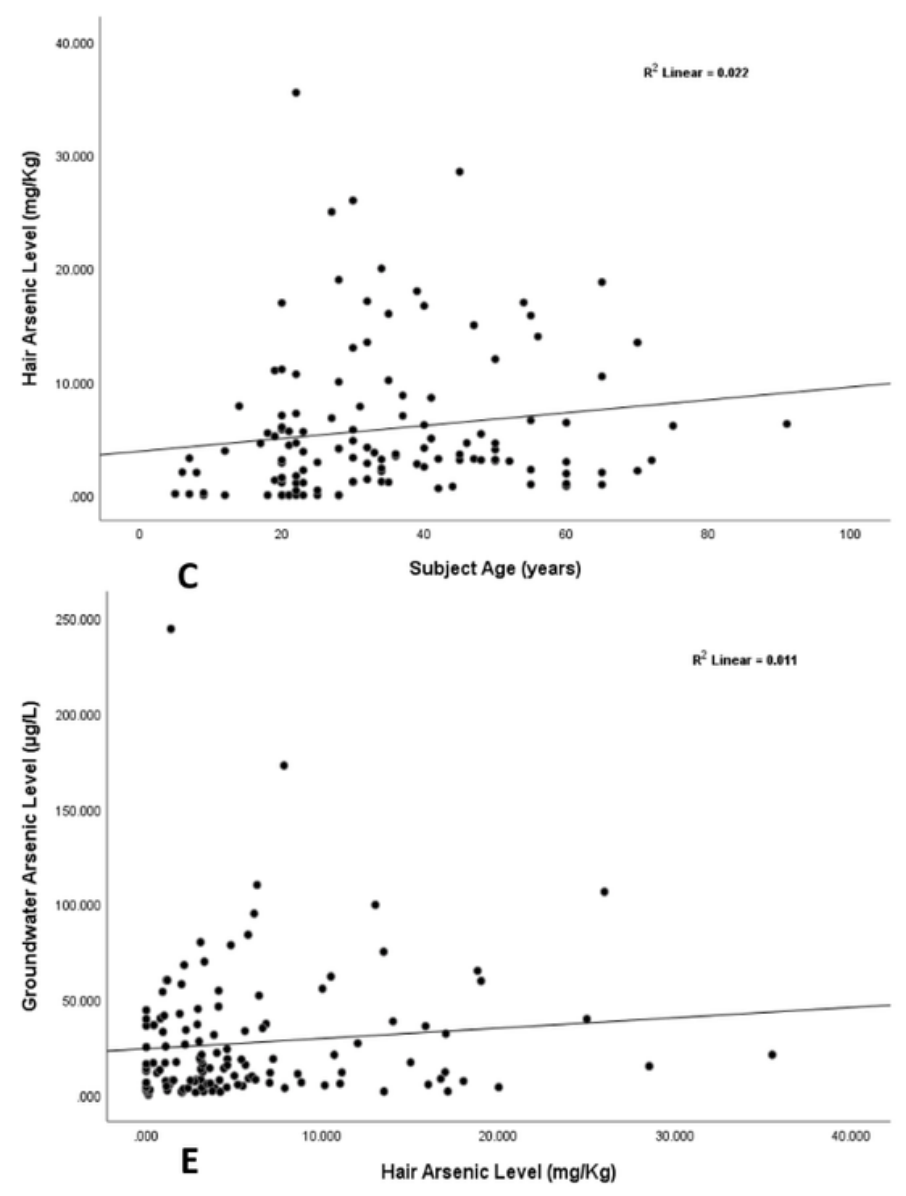
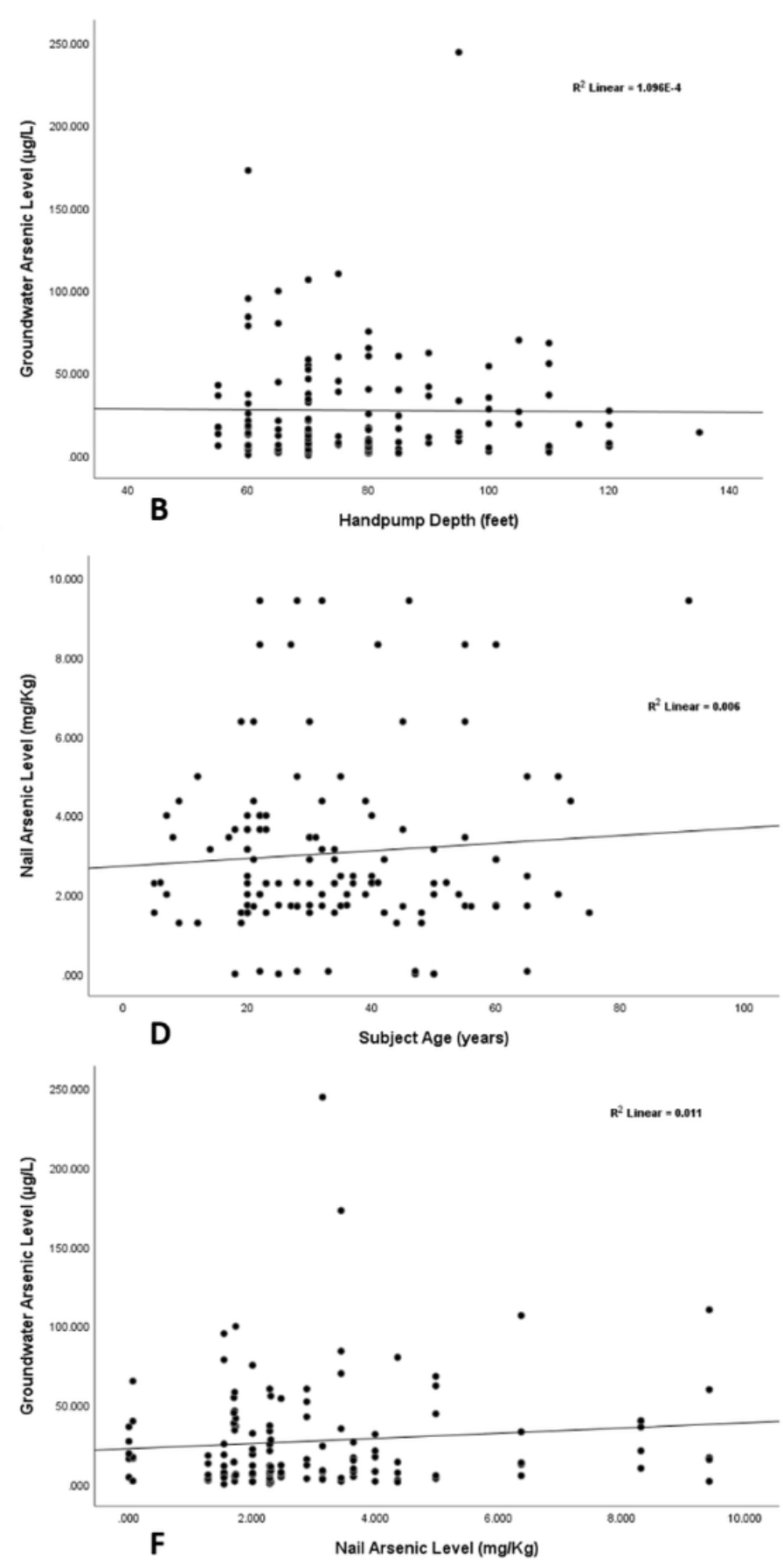

Figure 5

A. The scatterplot graph of groundwater arsenic concentration and age of the handpumps $(r=0.040$ \& $P<0.05)$. B. The scatterplot graph of groundwater arsenic concentration and depth of the handpumps $(r=$ negative \& $P<0.05)$. C. The scatterplot graph of hair arsenic concentrations and age of the subjects $(r=0.022 \& P<0.05)$. D. The scatterplot graph of nail arsenic concentrations and age of the subjects $(r=0.006 \& P<0.05)$. E. The scatterplot graph of groundwater arsenic concentration and hair arsenic level $(r=0.011 \& P<0.05)$. F. The scatterplot graph of groundwater arsenic concentration and nail arsenic level $(r=0.011 \& P<0.05)$. 


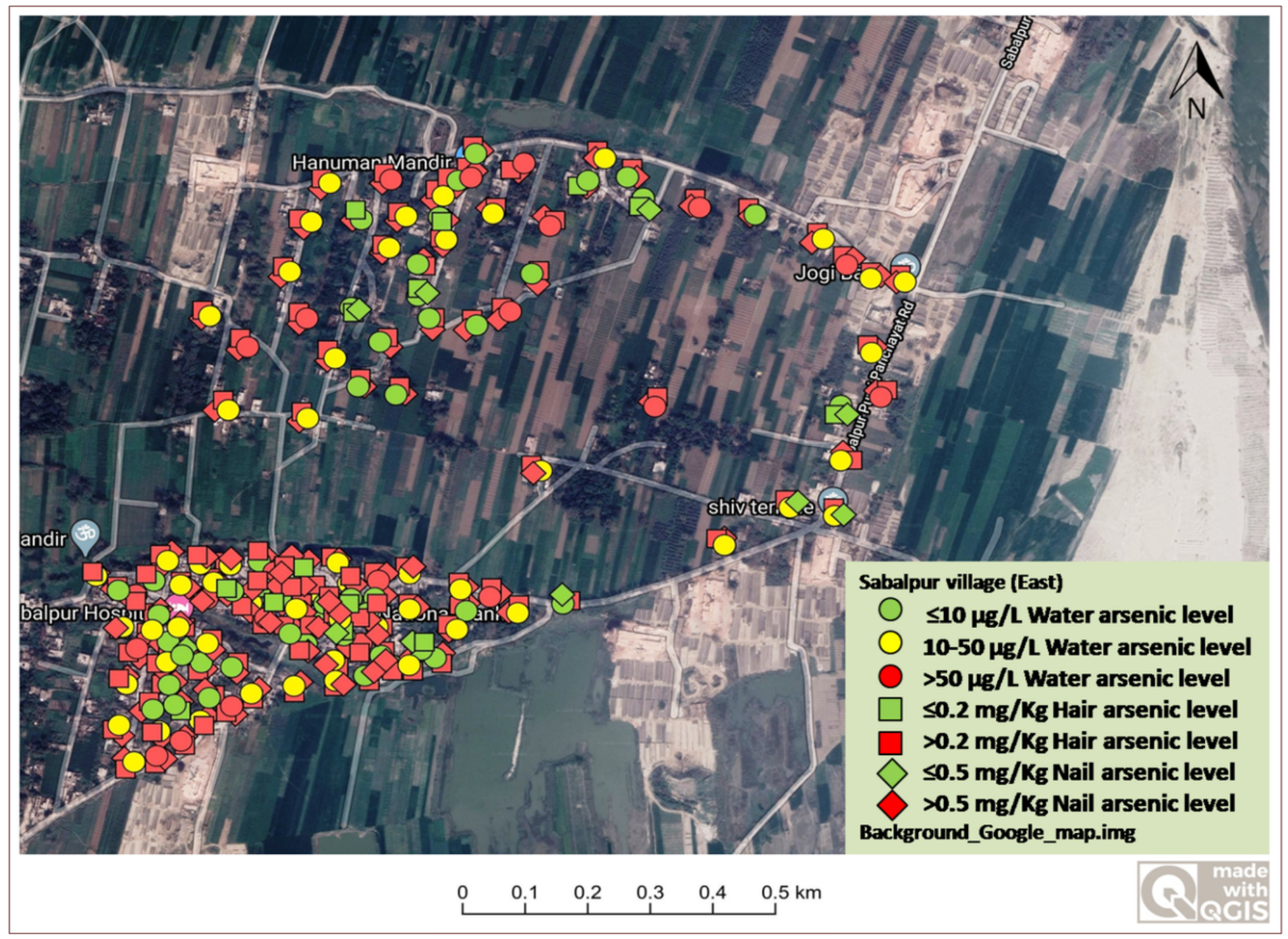

\section{Figure 6}

Thematic map showing synoptic view of arsenic level in groundwater, hair and nail samples overlaid using QGIS software (version 3.10.1-A Coruna) Note: The designations employed and the presentation of the material on this map do not imply the expression of any opinion whatsoever on the part of Research Square concerning the legal status of any country, territory, city or area or of its authorities, or concerning the delimitation of its frontiers or boundaries. This map has been provided by the authors. 


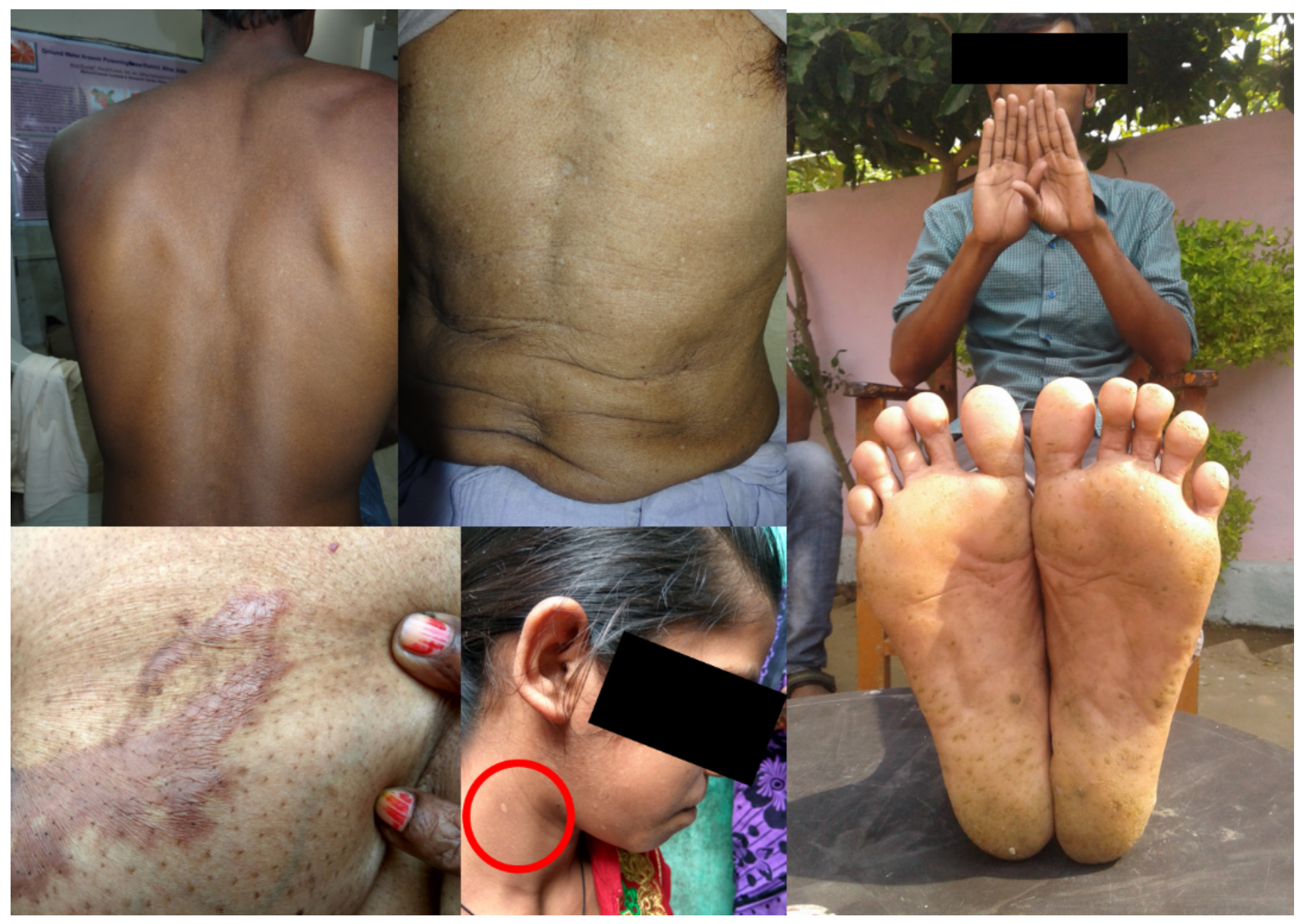

Figure 7

Clinical observation of village people with skin disorders 


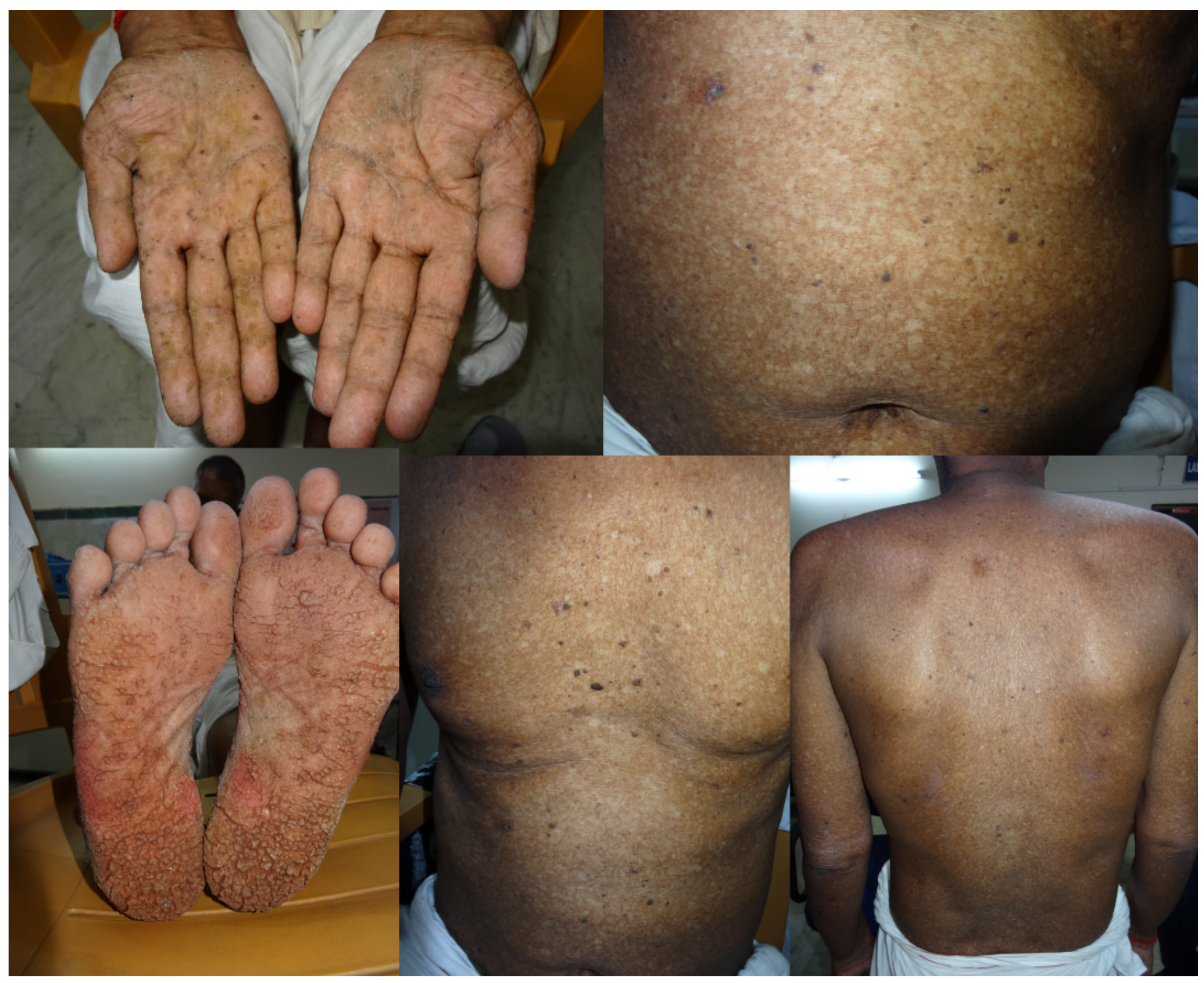

Figure 8

Arsenicosis symptoms in a renal cancer patient 


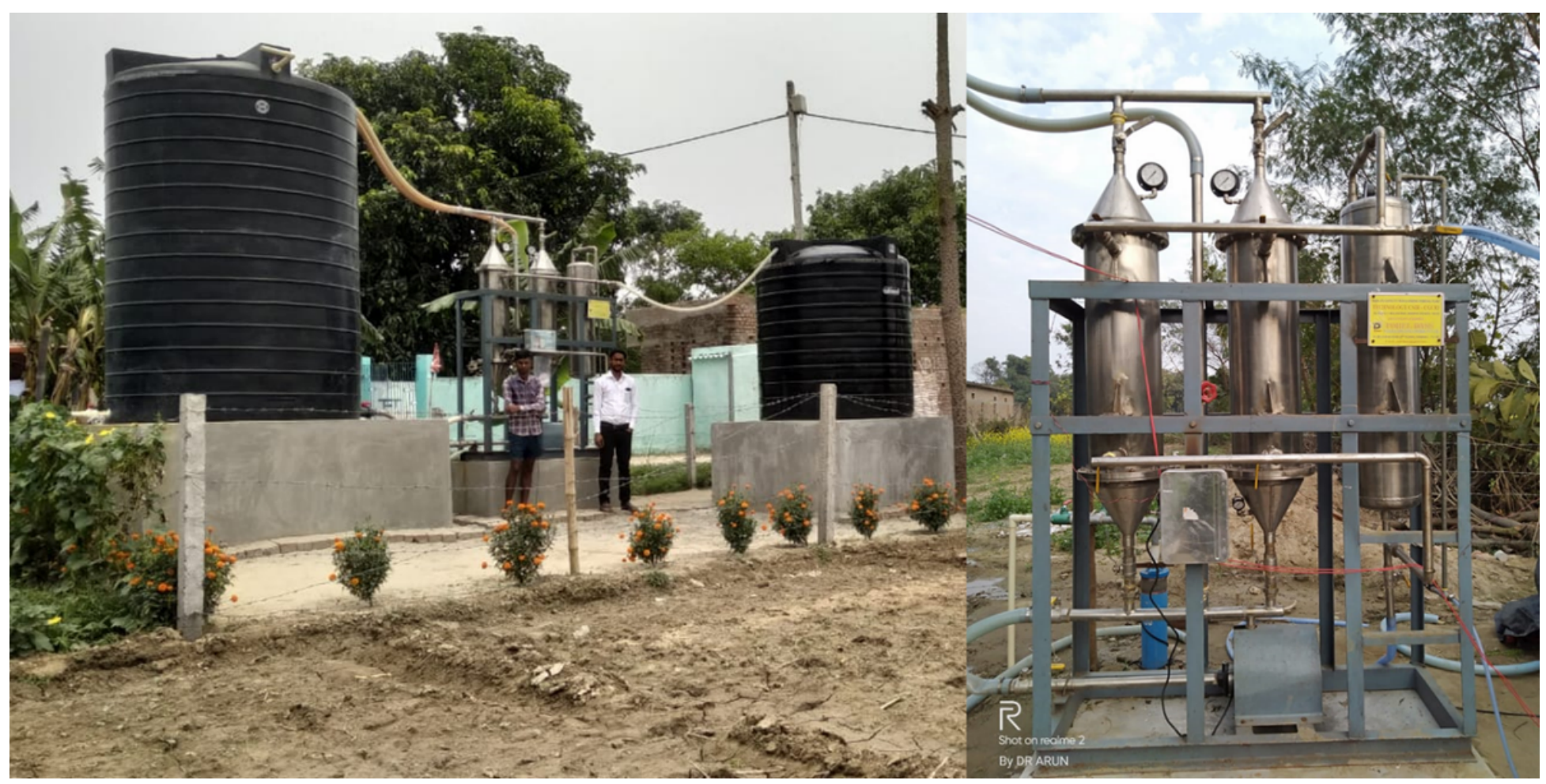

Figure 9

Mitigation unit (Arsenic Filter) installed in the village 